Prepared in cooperation with the Bureau of Reclamation

\title{
Dissolved-Solids Load in Henrys Fork Upstream from the Confluence with Antelope Wash, Wyoming, Water Years 1970-2009
}

Scientific Investigations Report 2010-5048 



\section{Dissolved-Solids Load in Henrys Fork Upstream from the Confluence with Antelope Wash, Wyoming, Water Years 1970-2009}

By Katharine Foster and Terry A. Kenney

Prepared in cooperation with the Bureau of Reclamation

Scientific Investigations Report 2010-5048 


\title{
U.S. Department of the Interior \\ KEN SALAZAR, Secretary \\ U.S. Geological Survey \\ Marcia K. McNutt, Director
}

\section{U.S. Geological Survey, Reston, Virginia: 2010}

\author{
For more information on the USGS — the Federal source for science about the Earth, its natural and living resources, \\ natural hazards, and the environment, visit http://www.usgs.gov or call 1-888-ASK-USGS \\ For an overview of USGS information products, including maps, imagery, and publications, \\ visit http://www.usgs.gov/pubprod \\ To order this and other USGS information products, visit http://store.usgs.gov
}

\begin{abstract}
Any use of trade, product, or firm names is for descriptive purposes only and does not imply endorsement by the U.S. Government.

Although this report is in the public domain, permission must be secured from the individual copyright owners to reproduce any copyrighted materials contained within this report.
\end{abstract}

Suggested citation:

Foster, K., and Kenney, T.A., 2010, Dissolved-solids load in Henrys Fork upstream from the confluence with Antelope Wash, Wyoming, water years 1970-2009: U.S. Geological Survey Scientific Investigations Report 2010-5048, 16 p. 


\section{Contents}

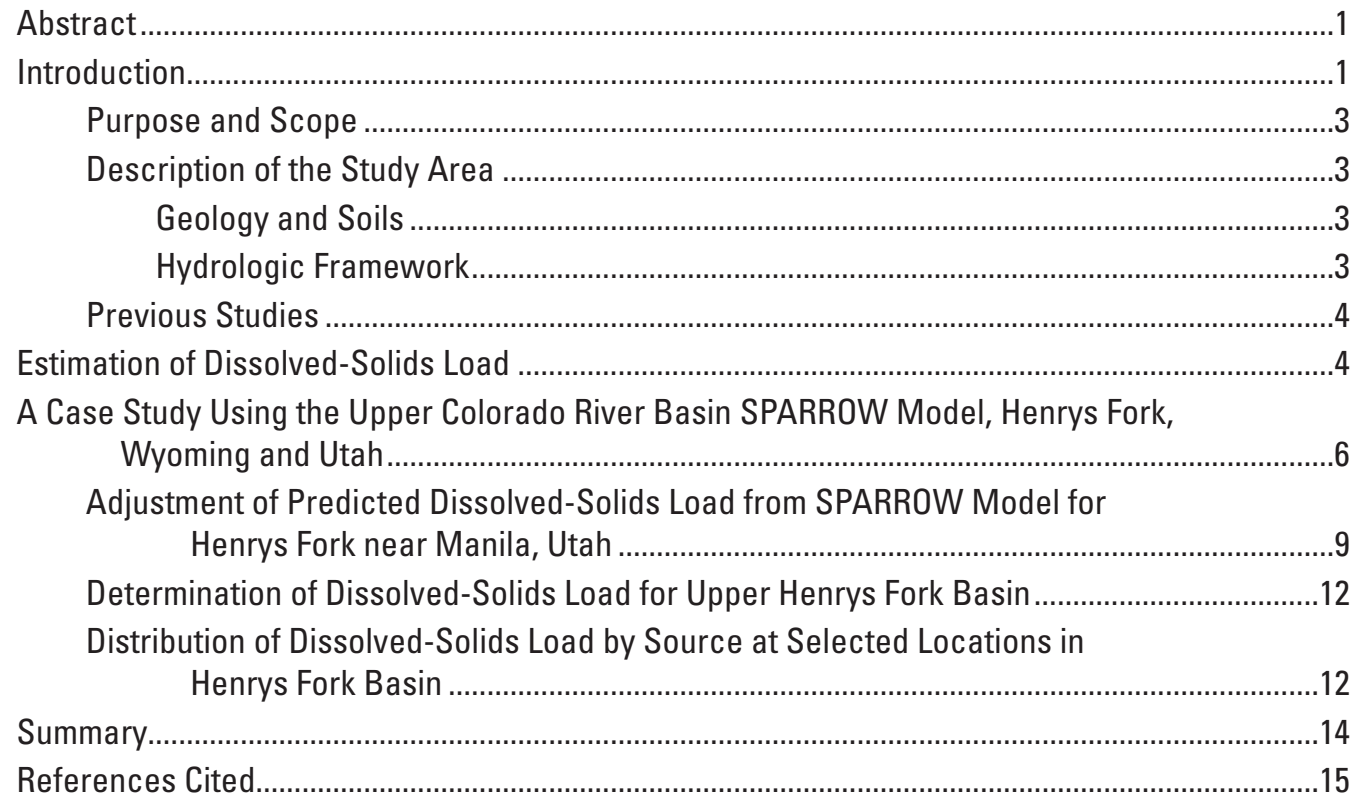

\section{Figures}

1. Map showing location of the study area and irrigated lands in the upper Henrys Fork Basin, Wyoming and Utah.

2-3. Graphs showing:

2. Daily mean streamflow and discrete values of dissolved-solids concentration during water-quality sampling at U.S. Geological Survey streamflow-gaging station 09229500, Henrys Fork near Manila, Utah, water years 1970-2009.

3. Annual streamflow and annual dissolved-solids load at streamflow-gaging station 09229500, Henrys Fork near Manila, Utah, water years 1970-2009

\section{Tables}

1. Annual streamflow and annual dissolved-solids load at U.S. Geological Survey streamflow-gaging station 09229500, Henrys Fork near Manila, Utah, water years 1970-2009

2. Ranked annual streamflow and annual dissolved-solids load from streamflow-gaging station 09229500, Henrys Fork near Manila, Utah, water years $1970-2009$.

3. Predicted and adjusted dissolved-solids load from SPARROW model for selected locations in the Henrys Fork Basin, Wyoming, water year 1991 
4. Dissolved-solids concentration and estimated mean dissolved-solids load in streamflow from Antelope Wash, Wyoming, August 2004 to September 2009

5. Dissolved-solids concentration and estimated daily dissolved-solids load in Peoples Canal, Wyoming, June 2004 to September 2009

6. Estimated dissolved-solids load in Peoples Canal, Wyoming, June 2004 to September 2009

\section{Conversion Factors and Datums}

\begin{tabular}{lcl}
\hline Multiply & By & To obtain \\
\hline \multicolumn{3}{c}{ Area } \\
\hline acre & 0.4047 & hectare $(\mathrm{ha})$ \\
acre & 0.004047 & square kilometer $\left(\mathrm{km}^{2}\right)$ \\
square mile $\left(\mathrm{mi}^{2}\right)$ & 2.590 & square kilometer $\left(\mathrm{km}^{2}\right)$ \\
\hline \multicolumn{3}{c}{ Volume } \\
\hline acre-feet $($ acre-ft) & 1,233 & cubic meter $\left(\mathrm{m}^{3}\right)$ \\
\hline \multicolumn{3}{c}{ flow rate } \\
\hline cubic foot per second $\left(\mathrm{ft}^{3} / \mathrm{s}\right)$ & 0.02832 & cubic meter per second $\left(\mathrm{m}^{3} / \mathrm{s}\right)$ \\
\hline ton & Mass \\
ton per day (ton/d) & 0.9072 & metric ton \\
tons per year & 0.9072 & metric ton per day \\
\hline
\end{tabular}

Horizontal coordinate information is referenced to the North American Datum of 1983 (NAD 83).

Concentrations of dissolved solids in water are given in milligrams per liter ( $\mathrm{mg} / \mathrm{L})$.

Water year is the 12-month period from 0 ctober 1 through September 30 and is designated by the year in which it ends. For example, the water year ending September 30, 2008, is called water year 2008.

\section{Acronyms and Abbreviations}

AMLE Adjusted Maximum Likelihood Estimation

BOR Bureau of Reclamation

LOADEST LOAD ESTimator computer program

NWIS National Water Information System

ROE residue on evaporation at 180 degrees Celsius

$\mathrm{R}^{2} \quad$ coefficient of determination

S-LOADEST LOAD ESTimator computer program run as an add-on in S-Plus

SOC sum of constituents

SPARROW Spatially Referenced Regression On Watershed attributes

S-PLUS computer-based statistical package

USGS U.S. Geological Survey 


\title{
Dissolved-Solids Load in Henrys Fork Upstream from the Confluence with Antelope Wash, Wyoming, Water Years 1970-2009
}

\author{
By Katharine Foster and Terry A. Kenney
}

\section{Abstract}

Annual dissolved-solids load at the mouth of Henrys Fork was estimated by using data from U.S. Geological Survey streamflow-gaging station 09229500, Henrys Fork near Manila, Utah. The annual dissolved-solids load for water years 1970-2009 ranged from 18,300 tons in 1977 to 123,300 tons in 1983. Annual streamflows for this period ranged from 14,100 acre-feet in 1977 to 197,500 acre-feet in 1983. The 25-percent trimmed mean dissolved-solids load for water years 1970-2009 was 44,300 tons per year at Henrys Fork near Manila, Utah.

Previous simulations using a SPAtially Referenced Regression On Watershed attributes (SPARROW) model for dissolved solids specific to water year 1991 conditions in the Upper Colorado River Basin predicted an annual dissolvedsolids load of 25,000 tons for the Henrys Fork Basin upstream from Antelope Wash. On the basis of computed dissolvedsolids load data from Henrys Fork near Manila, Utah, together with estimated annual dissolved-solids load from Antelope Wash and Peoples Canal, this prediction was adjusted to 37,200 tons. As determined by simulations with the Upper Colorado River Basin SPARROW model, approximately 56 percent (14,000 tons per year) of the dissolved-solids load at Henrys Fork upstream from Antelope Wash is associated with the 21,500 acres of irrigated agricultural lands in the upper Henrys Fork Basin.

\section{Introduction}

Irrigated agriculture represents the largest use of water in the Colorado River Basin (fig. 1) and contributes the second largest amount of dissolved solids to the surface-water system following natural sources (Iorns and others, 1965; U.S. Department of the Interior, 2003; Kenney and others, 2009). The primary cause of salt loading from irrigated lands is deep percolation $^{1}$ of irrigation water through salt-bearing soils and

${ }^{1}$ Water movement and losses below the root zone of the crop. underground shale formations (Natural Resources Conservation Service, 2006). Deep percolation can mobilize salts found naturally in soils. Therefore, one of the most important water-resource issues in the Colorado River Basin is control of dissolved solids as water moves downstream though the basin (U.S. Department of the Interior, 1999). The term "dissolved solids" is synonymous with the terms "salinity" and "salt." Natural processes and anthropogenic activities contribute to the dissolved-solids load in Colorado River Basin streams. Natural sources of salt include soils, geologic formations, and stream channels and banks (U.S. Department of the Interior, 2003). Agricultural, municipal, and industrial activities are potential anthropogenic sources of salt introduced into surface water. Agricultural irrigation practices can accelerate the dissolution of soluble materials that are present and concentrate salts in soils as plants consume water (Colorado River Basin Salinity Control Forum, 2002).

Following the Colorado River Salinity Control Act of 1974 (Public Law 93-320, amended as Public Law 98-569, 104-20, 104-127, and 106-459), the Colorado River Basin Salinity Control Forum has coordinated the implementation of Federal, State, and local salinity control projects (Colorado River Basin Salinity Control Forum, 1975). Irrigated agriculture has been the focus of many of these projects because changes to infrastructure and irrigation practices can yield substantial reductions in the transport of dissolved solids to streams (Colorado River Basin Salinity Control Forum, 2002).

Because of ongoing efforts to assess and control salinity from irrigated lands, the Bureau of Reclamation (BOR) needs to determine dissolved-solids loading to the Henrys Fork upstream from the confluence with Antelope Wash for irrigated areas of agriculture in Wyoming and Utah (fig. 1). To address this need, the U.S. Geological Survey (USGS), in cooperation with the BOR, conducted an investigation to estimate the mean annual dissolved-solids load associated with irrigated agricultural lands in the upper Henrys Fork Basin. About 21,500 acres of irrigated lands are in the upper Henrys Fork Basin (David Eckhart, Bureau of Reclamation, written commun., 2006). Of this total, about 15,900 acres are in Sweetwater and Uinta Counties in Wyoming, about 4,100 acres are in Summit County, Utah, and about 1,500 acres are in Daggett County, Utah (fig. 1). 


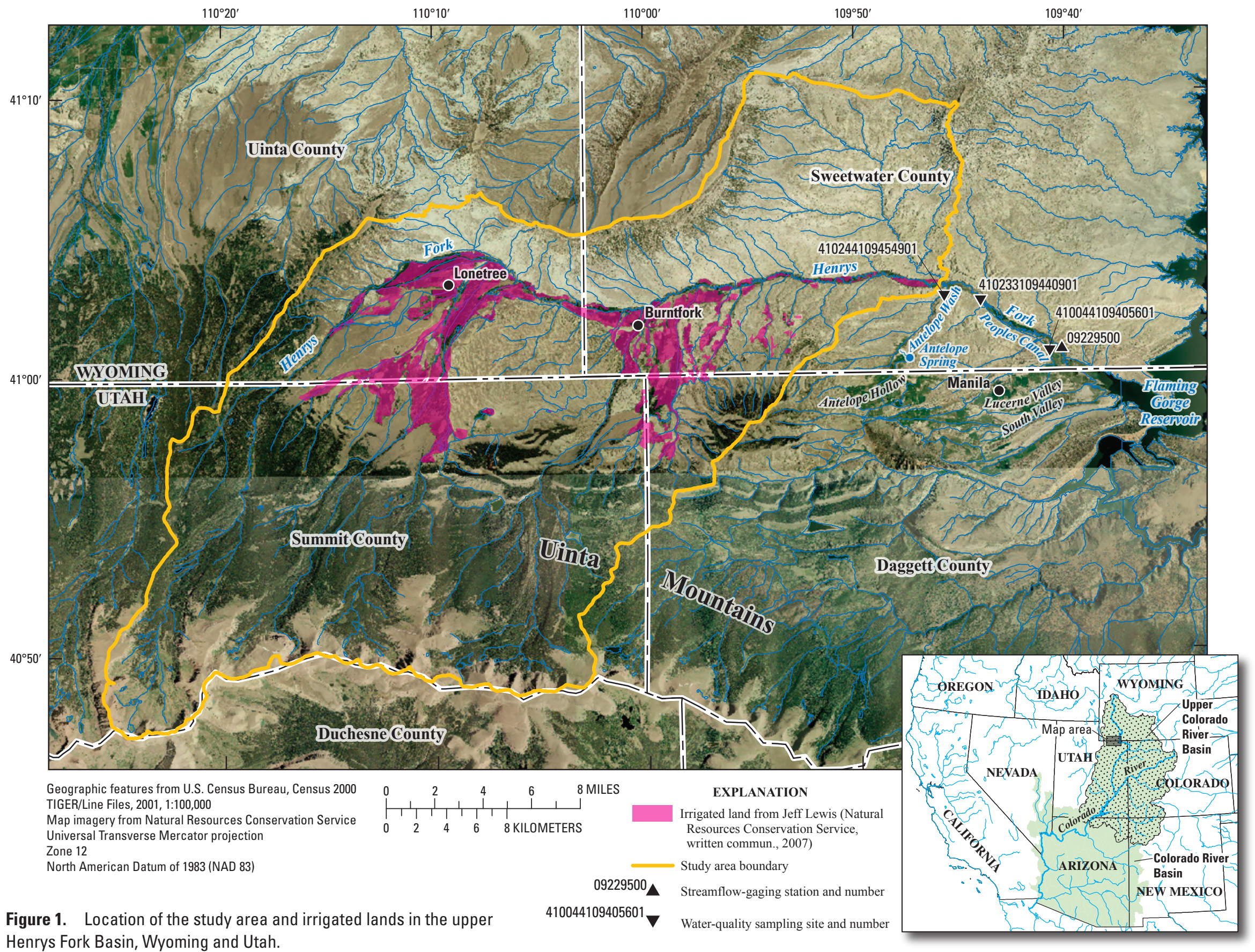




\section{Purpose and Scope}

This report presents the results of data analysis used to determine the dissolved solids contributed to Henrys Fork from the portion of the basin upstream from the confluence with Antelope Wash. Estimates of dissolved-solids load based on data from USGS streamflow-gaging station 09229500 , Henrys Fork near Manila, Utah, for water years 1970-2009 were compared with predicted dissolved-solids load from a SPAtially Referenced Regression On Watershed attributes (SPARROW) model specific to the Upper Colorado River Basin to determine dissolved-solids load and sources of dissolved-solids load in the study area.

\section{Description of the Study Area}

In this report, the study area is referred to as the upper Henrys Fork Basin (fig. 1) and is defined as the basin area of Henrys Fork upstream from the confluence of Antelope Wash. The study area encompasses parts of Sweetwater and Uinta Counties in Wyoming, and Daggett and Summit Counties in Utah. The towns of Lonetree and Burntfork, in southwestern Wyoming, are in the upper Henrys Fork Basin. Much of the climate, geology, surface water, and groundwater have been described by Lowham and others (1985), Mason and Miller (2004), and Gerner and others (2006).

\section{Geology and Soils}

The study area is underlain by sediments that make up the early Tertiary-age Wasatch, Green River, and Bridger Formations (Love and Christiansen, 1985). These formations consist of varied amounts of limestone (marls), shale, sandstone (partly tuffaceous), and mudstone that were deposited in lacustrine (Green River Formation) and fluvial (Wasatch and Bridger Formations) environments. Most of the land in the Wyoming portion of the study area is underlain by the Bridger Formation, which weathers into badlands, such as the area north of Henrys Fork (Koenig, 1960). Irrigated lands south of Henrys Fork are underlain by the Laney Member of the Green River Formation (Mason and Miller, 2004). Quaternary-age alluvium and colluvial deposits also are present along the flood plain of Henrys Fork as well as along smaller tributary drainages throughout the study area. These deposits consist primarily of sand and gravel that have been transported downstream from the Uinta Mountains.

Soils in the study area are derived from a variety of rock types, including shale, sandstone, and mudstone (Schwarz and Alexander, 1995). The most common soils in the study area are classified within the Luhon-Evanston complex. These soils are on 3- to 30-percent slopes, are in the shallow loamy ecological site ${ }^{2}$ and have a slightly sodic horizon (U.S. Department of Agriculture, 2004b). Where the Bridger Formation crops out, the soils are classified within the Roto-RockinchairRencot complex and the Blazon thin solum-Blazon-Lilsnake complex. The Roto-Rockinchair-Rencot complex is derived mainly from limestone and sandstone parent material, is on 1- to 10-percent slopes, and is in the shallow loamy to loamy ecological sites. The Blazon thin solum-Blazon-Lilsnake complex is derived from weathered shale and sandstone, is on 2- to 40-percent slopes, and is in the shale and shallow loamy ecological site. Both complexes have a slightly sodic horizon (U.S. Department of Agriculture, 2004b). Along the flood plain of the upper Henrys Fork, soils derived from the alluvial sediments are part of the Hagga-Cowestglen association. These soils are on 0- to 2-percent slopes. The Hagga component is in the subirrigated ecological site and has a slightly sodic horizon, whereas the Cowestglen component is in the lowland ecological site and does not have a sodic horizon (U.S. Department of Agriculture, 2004b). Therefore, soils developed from the Green River and Bridger Formations can contribute to salinity loading (Schwarz and Alexander, 1995).

\section{Hydrologic Framework}

The surface waters of the study area originate in the Uinta Mountains in the southwestern part of the basin and flow generally south to north to Henrys Fork then east through the study area and eventually discharge into Flaming Gorge Reservoir (fig. 1). Because precipitation in the study area is low, many streams in the study area are intermittent or ephemeral, with most flows resulting from local and regional snowmelt and rainfall runoff (Mason and Miller, 2004). Henrys Fork has the largest flow of any stream in the study area, and moderate to large flows are a result of runoff from snowmelt in mountainous areas in the northern and southwestern parts of the basin (Mason and Miller, 2004). Annual streamflow values for the period of record (water years 1929-2009) at Henrys Fork near Manila, Utah, range from 11,900 acrefeet (acre-ft) in 1934 to 197,500 acre-ft in 1983. The median annual streamflow for the period of record is 51,000 acre- $\mathrm{ft}$, and the median annual streamflow for the study period (water years 1970-2009) is 49,300 acre-ft. There is a break in the period of record from 1994 to 2001 at Henrys Fork near Manila, Utah, when the streamflow-gaging station was not in operation (USGS National Water Information System, NWIS; http://nwis.waterdata.usgs.gov).

\footnotetext{
${ }^{2} \mathrm{An}$ ecological site is distinctive kind of land with specific soil and physical characteristics that differs from other kinds of land in its ability to produce distinctive kinds and amounts of vegetation, and in its ability to respond similarly to management actions and natural disturbances (U.S. Department of Agriculture, 2004a).
} 
Snowmelt runoff, groundwater inflows, springs, or a combination of these sources maintain streamflows throughout most years in perennial reaches; whereas ephemeral reaches exist where streamflows generally are less than water losses to seepage, evaporation, diversions, or a combination of these factors. Antelope Wash originates from Antelope Spring in Antelope Hollow and then flows northeast to join Henrys Fork (Gerner and others, 2006; fig. 1). Peoples Canal diverts streamflow from Henrys Fork and delivers it to the Lucerne Valley for irrigation. Although Antelope Wash and Peoples Canal are not within the study area, the dissolvedsolids load contributed to Henrys Fork from Antelope Wash and the dissolved-solids load diverted into Peoples Canal are described in subsequent sections of this report.

\section{Previous Studies}

The most recent study of dissolved solids in the Henrys Fork Basin was an investigation to determine the amount of dissolved solids contributed to Flaming Gorge Reservoir from Lucerne Valley, South Valley, Antelope Hollow, and lower Henrys Fork near Manila, Utah (Gerner and others, 2006). The report includes a description of the occurrence and distribution of dissolved solids in water resources in or near the agricultural lands near Manila, Utah, downstream from the confluence of Henrys Fork and Antelope Wash. Some results from that study are used in this report.

Kenney and others (2009) documented the methods and data used to develop a SPAtially Referenced Regression On Watershed attributes (SPARROW) model for dissolved solids in the Upper Colorado River Basin for water year 1991. Published results include estimates of dissolved-solids load for all defined stream reaches in the basin with incremental catchments ranging from less than 1 square mile $\left(\mathrm{mi}^{2}\right)$ to $78 \mathrm{mi}^{2}$. The report describes the model-generated coefficients specific to their role in calculating dissolved-solids input and stream transport, and the applicability of the SPARROW model results to other time periods. Limitations and uncertainties associated with the model results and interpretation are also described.

\section{Estimation of Dissolved-Solids Load}

The USGS program LOADEST (Runkle and others, 2004), which can be run as an add-on program to a computerbased statistics package, S-PLUS (TIBCO Software, Inc., 2008), was used for estimating dissolved-solids load at USGS streamflow-gaging station 09229500, Henrys Fork near Manila, Utah, on the basis of data obtained from the NWIS (http://nwis.waterdata.usgs.gov). When the LOADEST program is run as an add-on to S-PLUS, it is referred to S-LOADEST. The S-LOADEST program is a menu-driven version of the LOAD Estimator (LOADEST) FORTRAN computer program of Runkel and others (2004) and uses values of streamflow and constituent concentration to develop regression models in nine different predefined formulations. The user then selects the most appropriate model formulated by LOADEST by evaluating statistical parameters that relate to model performance. The formulated regression model for estimating dissolved-solids load from a time series of streamflow data is then used to estimate daily dissolved-solids loads, which are aggregated into an annual dissolved-solids load. The calibration and estimation procedure used within S-LOADEST to estimate dissolved-solid load in Henrys Fork is based on the Adjusted Maximum Likelihood Estimation (AMLE) method (Cohn, 1988).

Data from Henrys Fork near Manila, Utah, used to calibrate the model included daily mean streamflow for water years 1970-93 and 2002-09, and 188 discrete water-quality samples collected intermittently from October 24, 1969, to November 20, 2008 (fig. 2). During water years 1994-2001, the streamflow-gaging station at Henrys Fork near Manila, Utah, was not in operation (fig. 2). Dissolved-solids concentrations in water-quality samples were analyzed at the USGS National Water Quality Laboratory in Lakewood, Colorado, using two analytical methods: (1) sum of constituents (SOC) and (2) residue on evaporation at 180 degrees Celsius (ROE). The standard analytical techniques for both methods are described in Fishman and Friedman (1989). Because of the widespread use of ROE analysis for samples collected in the Upper Colorado River Basin, ROE was the preferred dissolved-solids concentration analysis for this study. When ROE data were not available, SOC data were used. Because the relation between streamflow and water-quality data generally is not linear, S-LOADEST uses natural logarithm transformations to improve the model fit and normality of the residuals. The selected dissolved-solids regression model for Henrys Fork near Manila, Utah, is given by equation 1:

1n $L=4.16+0.749 \ln Q-0.127 \sin (2 \pi$ dtime $)+0.072 \cos (2 \pi$ dtime $),(1)$

where

$L \quad$ represents the daily dissolved-solids load, in tons per day;

$Q \quad$ represents daily mean streamflow, in cubic feet per second; and

dtime represents decimal time, which is computed by dividing the day of the year, numbered 1 through 365 , by 365 .

The model in equation 1 is an appropriate model because the estimated dissolved-solids load had a large coefficient of determination $\left(\mathrm{R}^{2}\right)$ value and small values of residual variance and root mean square error. On the basis of water-quality and streamflow data from station 09229500 , the $\mathrm{R}^{2}$ value for equation 1 is 0.9699 , the estimated residual variance ${ }^{3}$ is 0.036 , and

\footnotetext{
${ }^{3}$ Estimated residual variance is the adjusted maximum likelihood estimation variance corrected for the number of observations and number of parameters in the regression model.
} 


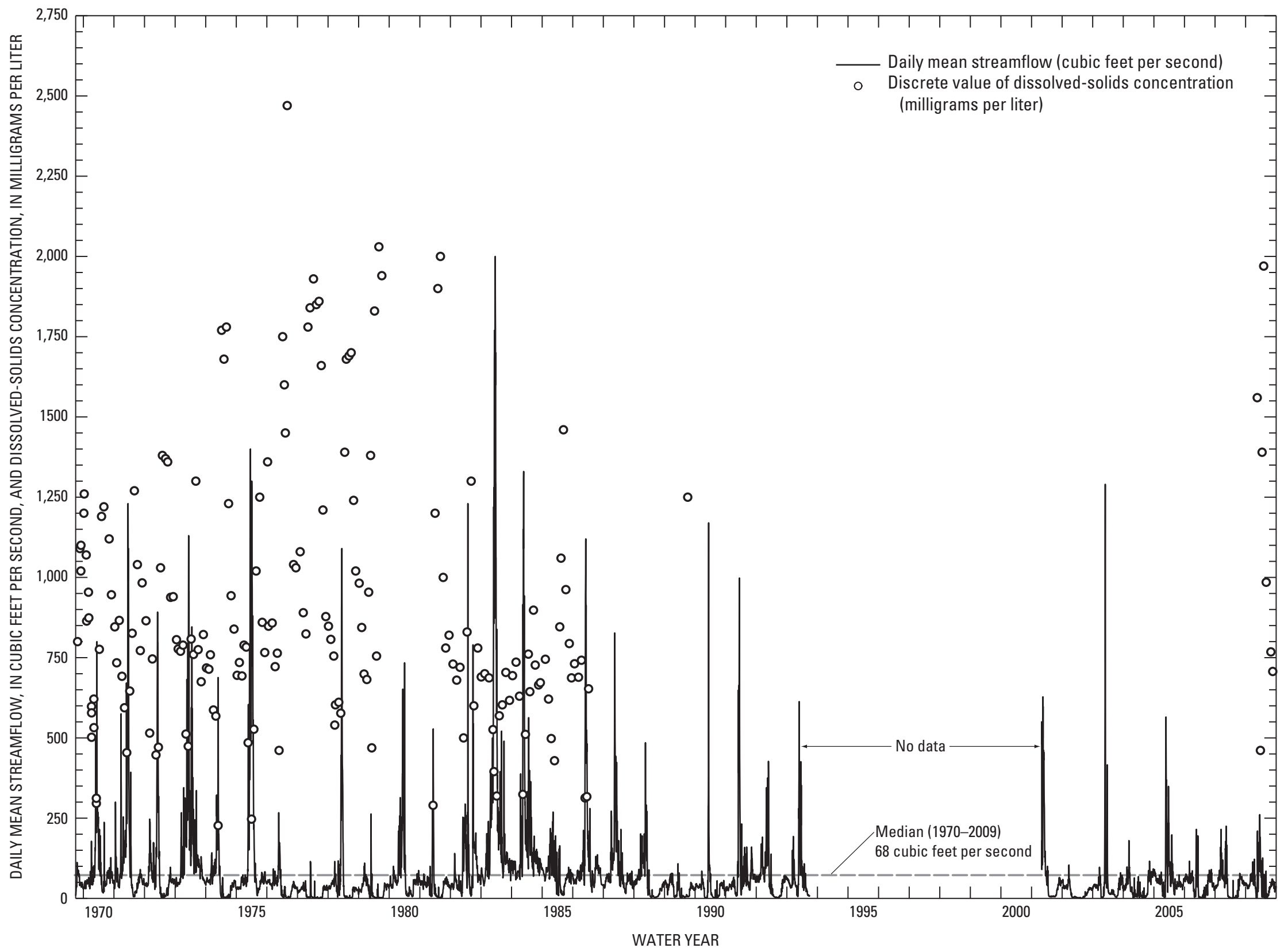

Figure 2. Daily mean streamflow and discrete values of dissolved-solids concentration during water-quality sampling at U.S. Geological Survey streamflow-gaging station 09229500, Henrys Fork near Manila, Utah, water years 1970-2009. 
the root mean square error is 17 percent. The model shown in equation 1 was determined to be the most appropriate model for the available data because the period of dissolved-solid load estimation (October 1, 1969, to September 30, 1993, and May 1, 2001, to November 20, 2008) was extended substantially beyond the period containing calibration data (October 24, 1969 to July 9, 1986 and May 19, 2008 to November 20,2008). Therefore, no models with annual time terms were considered.

Estimated annual dissolved-solids load from the S-LOADEST program for each water year are shown in table 1 and figure 3 . The mean annual mean daily dissolvedsolids load for water years 1970-2009 is 133 tons. The 95-percent confidence interval for this value ranges from 127 to 139 tons. The mean annual dissolved-solids load for water years $1970-2009$ is 48,700 tons, and the median annual dissolved-solids load for the same period is 45,400 tons (table 1; fig. 3). Annual streamflow ranged from 14,100 acre-ft in 1977 to 197,500 acre-ft in 1983.

The annual dissolved-solids load decreased from water years 1970-93 to water years 2002-09 (fig. 3). This decrease probably is because the period 2002-09 is characterized by dry years, whereas the period $1970-93$ is characterized by wet and dry years (fig. 2). The median streamflow for water years $1970-93$ is 76 cubic feet per second $\left(\mathrm{ft}^{3} / \mathrm{s}\right)$, whereas the median streamflow for water years $2002-09$ is $47 \mathrm{ft}^{3} / \mathrm{s}$, which is less than the median streamflow of $68 \mathrm{ft}^{3} / \mathrm{s}$ for water years 1970-2009. Other possible reasons for the decrease in dissolved-solids load include changes in land management practices, changes in water use, or a combination of these and unknown factors.

When data are highly varied, calculation of mean values can be more valid when several of the largest and smallest values are "trimmed." The most common method of trimming is removing 25 percent of the largest and smallest values, resulting in a "trimmed mean" or "25-percent trimmed mean" (Helsel and Hirsch, 2002). Values for the annual dissolvedsolids load data were first ranked largest to smallest (table 2). The 25-percent trimmed mean was then computed on the middle 50 percent of the values. This approach resulted in the best estimate of annual load because such estimates are not influenced by the most extreme (and perhaps anomalous) values (Helsel and Hirsch, 2002). The calculated 25-percent trimmed mean is 44,300 tons per year and is used as the best estimate of annual dissolved-solids load for water years 1970-2009.

\section{A Case Study Using the Upper Colorado River Basin SPARROW Model, Henrys Fork, Wyoming and Utah}

The USGS, in cooperation with the BOR and the Bureau of Land Management, developed a dissolved-solids SPARROW model specific to the Upper Colorado River Basin (Kenney and others, 2009). The SPARROW model uses a mass-balance approach to examine the production and transport of instream constituent mass, or flux, on the basis of a nonlinear weighted least-squares regression technique. Coefficients for defined contaminant sources, landscape transport characteristics, and aquatic transport characteristics are determined through iterative calibration with contaminant load from streamflow and water-quality data at stream-monitoring sites. The coefficients represent an average condition of the role each source term and characteristic play throughout the basin of interest, assuming an unbiased distribution of the monitoring sites used in model calibration (Kenney and others, 2009). These coefficients are then applied to the SPARROW model, and contaminant load estimates can be generated for each of the incremental stream reaches that describe the basin of interest.

The SPARROW model was calibrated by using dissolved-solids load for water year 1991 at 218 streammonitoring sites throughout the Upper Colorado River Basin (Kenney and others, 2009). The prediction error is approximately 51 percent (Kenney and others, 2009). The 11 defined sources for the model were 7 geologic source groups, 3 irrigated agricultural land groups, and 1 point-source associated with 7 large saline springs and 6 reservoirs. Six landscape transport characteristics and terms associated with climate, soils, vegetation, and elevation were found to be statistically significant in describing the transport of dissolved solids to streams in the Upper Colorado River Basin (Kenney and others, 2009).

Simulation results from the SPARROW model for the Upper Colorado River Basin include estimates of dissolvedsolids load for water year 1991 at more than 10,000 unique stream reaches throughout the Upper Colorado River Basin. In the model, the $520 \mathrm{mi}^{2}$ of the Henrys Fork drainage is represented by 57 unique stream reaches. Although the Henrys Fork drainage basin was included in the SPARROW model, estimated dissolved-solids load results for reaches in that basin 
Table 1. Annual streamflow and annual dissolved-solids load at U.S. Geological Survey streamflow-gaging station 09229500, Henrys Fork near Manila, Utah, water years 1970-2009.

\begin{tabular}{|c|c|c|c|c|c|}
\hline \multirow[b]{2}{*}{ Water year } & \multirow[b]{2}{*}{$\begin{array}{c}\text { Annual } \\
\text { streamflow } \\
\text { (acre-feet) }\end{array}$} & \multicolumn{4}{|c|}{ Dissolved-solids load } \\
\hline & & $\begin{array}{l}\text { Lower 95-percent } \\
\text { confidence limit for the } \\
\text { estimated mean daily load } \\
\text { (tons/day) }\end{array}$ & $\begin{array}{l}\text { Estimated mean } \\
\text { daily load } \\
\text { (tons/day) }\end{array}$ & $\begin{array}{c}\text { Upper 95-percent } \\
\text { confidence limit for the } \\
\text { estimated mean daily load } \\
\text { (tons/day) }\end{array}$ & $\begin{array}{c}\text { Estimated annual } \\
\text { load } \\
\text { (tons) }\end{array}$ \\
\hline 1970 & 61,900 & 144 & 150 & 156 & 54,900 \\
\hline 1971 & 98,000 & 190 & 199 & 208 & 72,600 \\
\hline 1972 & 64,600 & 138 & 144 & 151 & 52,800 \\
\hline 1973 & 115,000 & 221 & 232 & 243 & 84,600 \\
\hline 1974 & 54,800 & 129 & 135 & 140 & 49,100 \\
\hline 1975 & 114,100 & 195 & 207 & 219 & 75,400 \\
\hline 1976 & 33,400 & 93 & 97 & 101 & 35,500 \\
\hline 1977 & 14,100 & 48 & 50 & 52 & 18,300 \\
\hline 1978 & 47,500 & 99 & 104 & 109 & 38,000 \\
\hline 1979 & 19,100 & 58 & 60 & 63 & 22,000 \\
\hline 1980 & 55,000 & 122 & 127 & 133 & 46,700 \\
\hline 1981 & 35,400 & 92 & 96 & 100 & 35,000 \\
\hline 1982 & 55,100 & 132 & 138 & 144 & 50,200 \\
\hline 1983 & 197,500 & 319 & 338 & 358 & 123,300 \\
\hline 1984 & 132,600 & 258 & 271 & 284 & 99,000 \\
\hline 1985 & 63,400 & 156 & 162 & 169 & 59,200 \\
\hline 1986 & 88,300 & 182 & 190 & 199 & 69,400 \\
\hline 1987 & 75,600 & 168 & 175 & 182 & 63,900 \\
\hline 1988 & 47,600 & 116 & 121 & 126 & 44,200 \\
\hline 1989 & 19,700 & 62 & 65 & 67 & 23,600 \\
\hline 1990 & 28,200 & 73 & 76 & 79 & 27,700 \\
\hline 1991 & 55,900 & 125 & 130 & 136 & 47,600 \\
\hline 1992 & 51,000 & 123 & 128 & 134 & 47,000 \\
\hline 1993 & 47,600 & 116 & 120 & 125 & 44,000 \\
\hline 2002 & 16,300 & 53 & 55 & 58 & 20,200 \\
\hline 2003 & 34,100 & 83 & 87 & 90 & 31,600 \\
\hline 2004 & 20,600 & 64 & 67 & 70 & 24,500 \\
\hline 2005 & 54,200 & 133 & 138 & 144 & 50,400 \\
\hline 2006 & 30,800 & 88 & 91 & 95 & 33,400 \\
\hline 2007 & 33,400 & 90 & 93 & 97 & 34,100 \\
\hline 2008 & 35,400 & 96 & 100 & 104 & 36,600 \\
\hline 2009 & 45,000 & 111 & 115 & 120 & 42,100 \\
\hline Mean & 57,700 & 127 & 133 & 139 & 48,700 \\
\hline Median & 49,300 & 119 & 124 & 129 & 45,400 \\
\hline
\end{tabular}




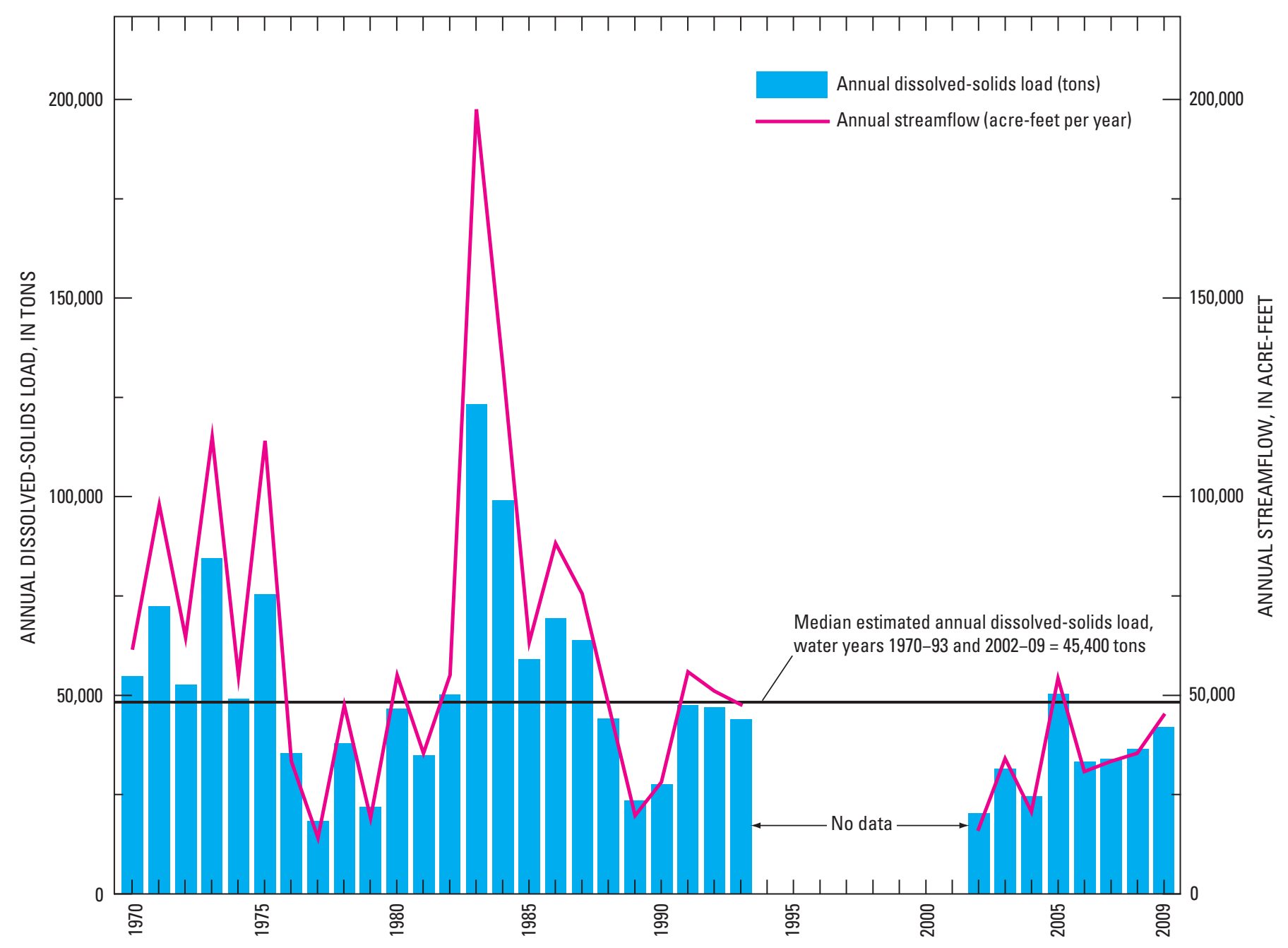

Figure 3. Annual streamflow and annual dissolved-solids load at streamflow-gaging station 09229500, Henrys Fork near Manila, Utah, water years 1970-2009.

were not included in the final report by Kenney and others (2009). Those results are published as part of this report and are shown in table 3 . All methods for determining the model results are described in Kenney and others (2009).

The dissolved-solids load predicted by using the SPARROW model for Henrys Fork near Manila, Utah, for water year 1991 was 29,600 tons. Considering the prediction error (51 percent) associated with the model, the predicted dissolved-solid load has a range of uncertainty of 14,500 tons to 44,700 tons (table 3 ). The results generated by the model represent basin-averaged conditions. Water developments and local point sources of dissolved solids, such as springs, can cause differences between predicted dissolved-solids load and actual dissolved-solids load because local influences on dissolved-solids loading to streams are not represented in the model at finer scales (Kenney and others, 2009). 
Table 2. Ranked annual streamflow and annual dissolvedsolids load from streamflow-gaging station 09229500, Henrys Fork near Manila, Utah, water years 1970-2009.

\begin{tabular}{|c|c|c|c|}
\hline Rank & Water year & $\begin{array}{c}\text { Annual } \\
\text { streamflow } \\
\text { (acre-feet) }\end{array}$ & $\begin{array}{c}\text { Annual } \\
\text { dissolved-solids } \\
\text { load } \\
\text { (tons) }\end{array}$ \\
\hline 1 & 1983 & 197,500 & 123,300 \\
\hline 2 & 1984 & 132,600 & 99,000 \\
\hline 3 & 1973 & 115,000 & 84,600 \\
\hline 4 & 1975 & 114,100 & 75,400 \\
\hline 5 & 1971 & 98,000 & 72,600 \\
\hline 6 & 1986 & 88,300 & 69,400 \\
\hline 7 & 1987 & 75,600 & 63,900 \\
\hline 8 & 1985 & 63,400 & 59,200 \\
\hline \multicolumn{2}{|c|}{ 75th percentile } & & 55,900 \\
\hline 9 & 1970 & 61,900 & 54,900 \\
\hline 10 & 1972 & 64,600 & 52,800 \\
\hline 11 & 2005 & 54,200 & 50,400 \\
\hline 12 & 1982 & 55,100 & 50,200 \\
\hline 13 & 1974 & 54,800 & 49,100 \\
\hline 14 & 1991 & 55,900 & 47,600 \\
\hline 15 & 1992 & 51,000 & 47,000 \\
\hline 16 & 1980 & 55,000 & 46,700 \\
\hline \multicolumn{3}{|c|}{ 50th percentile (median) } & 45,400 \\
\hline 17 & 1988 & 47,600 & 44,200 \\
\hline 18 & 1993 & 47,600 & 44,000 \\
\hline 19 & 2009 & 45,000 & 42,100 \\
\hline 20 & 1978 & 47,500 & 38,000 \\
\hline 21 & 2008 & 35,400 & 36,600 \\
\hline 22 & 1976 & 33,400 & 35,500 \\
\hline 23 & 1981 & 35,400 & 35,000 \\
\hline 24 & 2007 & 33,400 & 34,100 \\
\hline \multicolumn{3}{|c|}{ 25th percentile } & 33,900 \\
\hline 25 & 2006 & 30,800 & 33,400 \\
\hline 26 & 2003 & 34,100 & 31,600 \\
\hline 27 & 1990 & 28,200 & 27,700 \\
\hline 28 & 2004 & 20,600 & 24,500 \\
\hline 29 & 1989 & 19,700 & 23,600 \\
\hline 30 & 1979 & 19,100 & 22,000 \\
\hline 31 & 2002 & 16,300 & 20,200 \\
\hline 32 & 1977 & 14,100 & 18,300 \\
\hline \multicolumn{3}{|c|}{ 25-percent trimmed mean } & 44,300 \\
\hline
\end{tabular}

\section{Adjustment of Predicted Dissolved-Solids Load from SPARROW Model for Henrys Fork near Manila, Utah}

Consideration of local hydrology is needed to reasonably compare results generated by the model with observed dissolved-solids load. Two features, Antelope Springs in Antelope Wash and Peoples Canal, which diverts water from Henrys Fork, were not represented in the SPARROW model and needed to be considered in order to compare results generated by the model with observed dissolved-solids load.

The dissolved-solid load associated with Antelope Springs was evaluated by using monitoring data collected in Antelope Wash. Water-quality data were collected in Antelope Wash (site 410244109454901) from August 2004 to September 2009 and analyzed as described by Gerner and others (2006). These data may be obtained from the NWIS (http://nwis.waterdata.usgs.gov). Ten samples were analyzed for dissolved-solids concentrations using the ROE method. A regression equation between ROE and specific conductance was determined by using the results from the 10 samples. This equation was then used to estimate the dissolved-solids concentrations in the remaining 20 samples for which only specific-conductance data were available. On the basis of these sampling results, the annual dissolved-solids load discharged from Antelope Wash was estimated to be 9,200 tons (table 4).

The annual dissolved-solids load for Antelope Wash was predicted to be 2,700 tons by using the SPARROW model (table 3). The SPARROW model underestimated the dissolved-solids load in this reach because the effect of the point-source dissolved-solids load associated with Antelope Springs was not represented in the model. The predicted dissolved-solids load (2,700 tons) for Antelope Wash was subtracted from the estimated annual dissolved-solids load ( 9,200 tons) determined from sampling in Antelope Wash. The difference of 6,500 tons, representing the contribution from Antelope Springs, was added to the SPARROW prediction of 29,600 tons for the Henrys Fork near Manila, Utah, resulting in an adjusted dissolved-solids load of 36,100 tons for the Henrys Fork near Manila, Utah, for water year 1991.

In contrast to Antelope Springs, the Peoples Canal diverts water and therefore dissolved-solids load from Henrys Fork. Water is diverted upstream from the streamflow-gaging station on Henrys Fork near Manila, Utah. Because Peoples Canal was not represented in the SPARROW model, the predicted dissolved-solids load for Henrys Fork includes the dissolved-solids load associated with the canal. In order to make the comparison with the dissolved-solids load estimated for Henrys Fork near Manila, Utah (site 09229500), from the LOADEST program, the SPARROW results need to be 
Table 4. Dissolved-solids concentration and estimated mean dissolved-solids load in streamflow from Antelope Wash, Wyoming, August 2004 to September 2009.

$\left[\mathrm{ft}^{3} / \mathrm{s}\right.$, cubic feet per second; $\mu \mathrm{S} / \mathrm{cm}$, microsiemens per centimeter; ${ }^{\circ} \mathrm{C}$, degrees Celsius; ROE, residue on evaporation at $180^{\circ} \mathrm{C} ; \mathrm{mg} / \mathrm{L}$, milligrams per liter; ,-- no data]

\begin{tabular}{|c|c|c|c|c|c|}
\hline Date & $\begin{array}{l}\text { Streamflow, } \\
\text { instantaneous } \\
\left(\mathrm{ft}^{3} / \mathrm{s}\right)\end{array}$ & $\begin{array}{l}\text { Specific conductance } \\
\left(\mu \mathrm{S} / \mathrm{cm} \text { at } 25^{\circ} \mathrm{C}\right)\end{array}$ & $\begin{array}{c}\text { Dissolved-solids } \\
\text { concentration, ROE } \\
\text { (mg/L) }\end{array}$ & $\begin{array}{c}\text { Estimated daily } \\
\text { dissolved-solids } \\
\text { concentration }{ }^{1} \\
\text { (mg/L) }\end{array}$ & $\begin{array}{c}\text { Estimated daily } \\
\text { dissolved-solids load² } \\
\text { (tons) }\end{array}$ \\
\hline $8 / 10 / 2004$ & 4.3 & 3,640 & 3,580 & 3,580 & 15,150 \\
\hline $9 / 14 / 2004$ & 3.0 & 4,160 & 4,080 & 4,080 & 12,000 \\
\hline $10 / 26 / 2004$ & 4.1 & 4,140 & -- & 4,120 & 16,600 \\
\hline $11 / 22 / 2004$ & 3.8 & 4,320 & 4,450 & 4,450 & 16,600 \\
\hline $1 / 19 / 2005$ & 2.6 & 4,150 & -- & 4,130 & 10,600 \\
\hline $2 / 24 / 2005$ & 2.3 & 4,030 & 4,080 & 4,080 & 9,200 \\
\hline $4 / 5 / 2005$ & 1.6 & 4,560 & -- & 4,490 & 7,100 \\
\hline $6 / 1 / 2005$ & 1.3 & 4,470 & 4,250 & 4,250 & 5,400 \\
\hline $6 / 13 / 2007$ & 1.9 & 3,690 & -- & 3,720 & 7,000 \\
\hline $7 / 10 / 2007$ & 1.2 & 3,670 & -- & 3,700 & 4,400 \\
\hline $8 / 14 / 2007$ & 2.2 & 3,840 & 3,950 & 3,950 & 8,600 \\
\hline $9 / 27 / 2007$ & 2.2 & 3,860 & -- & 3,870 & 8,400 \\
\hline $11 / 8 / 2007$ & 2.1 & 4,100 & -- & 4,080 & 8,400 \\
\hline $12 / 13 / 2007$ & 1.5 & 4,310 & -- & 4,270 & 6,300 \\
\hline $2 / 13 / 2008$ & 1.4 & 3,930 & 3,970 & 3,970 & 5,500 \\
\hline $3 / 19 / 2008$ & 1.9 & 3,750 & -- & 3,770 & 7,100 \\
\hline $4 / 10 / 2008$ & 1.6 & 3,870 & -- & 3,880 & 6,100 \\
\hline $5 / 20 / 2008$ & 1.0 & 4,180 & -- & 4,150 & 3,900 \\
\hline $6 / 9 / 2008$ & 1.4 & 4,200 & -- & 4,010 & 5,500 \\
\hline $7 / 17 / 2008$ & 3.4 & 3,460 & 3,450 & 3,450 & 11,500 \\
\hline $8 / 25 / 2008$ & 3.1 & 3,750 & -- & 3,770 & 11,500 \\
\hline $9 / 30 / 2008$ & 1.8 & 3,900 & 3,990 & 3,990 & 7,100 \\
\hline $12 / 3 / 2008$ & 2.5 & 4,020 & -- & 4,010 & 9,900 \\
\hline 2/19/2009 & 1.5 & 4,190 & 4,090 & 4,090 & 6,000 \\
\hline $4 / 6 / 2009$ & 3.1 & 3,810 & -- & 3,830 & 11,700 \\
\hline $5 / 20 / 2009$ & 1.2 & 4,220 & -- & 4,190 & 4,900 \\
\hline $6 / 4 / 2009$ & 1.6 & 3,980 & -- & 3,980 & 6,300 \\
\hline $7 / 9 / 2009$ & 7.5 & 2,890 & -- & 3,010 & 22,200 \\
\hline $8 / 4 / 2009$ & 4.2 & 3,270 & -- & 3,350 & 13,800 \\
\hline $9 / 3 / 2009$ & 2.3 & 3,720 & -- & 3,750 & 8,500 \\
\hline Mean & 2.5 & & & 3,900 & 9,200 \\
\hline
\end{tabular}

${ }^{1}$ Values were determined from analysis of residue on evaporation at $180^{\circ} \mathrm{C}(\mathrm{ROE})$ or by using regression equation developed from relation between $\mathrm{ROE}$ and specific conductance (SC): Dissolved solids concentration $=0.8881 \mathrm{SC}+441.9$.

${ }^{2}$ Individual average dissolved-solids concentrations $\left(D S_{\text {conc }}\right)$ were extrapolated to average daily dissolved-solids load $\left(D S_{\text {load }}\right)$ values by using the equation $D S_{\text {load }}=D S_{\text {conc }} \times 0.002697 \times$ streamflow $\times 365$, where streamflow is the instantaneous streamflow. 
adjusted to remove the dissolved-solids load associated with the canal.

The dissolved-solids load associated with Peoples Canal was determined from monitoring data. Water-quality data were collected at two sites on the canal (site 410233109440901 and 410044109405601) from June 2004 to September 2009 and analyzed as described in Gerner and others (2006). These data may be obtained from the NWIS (http://nwis.waterdata.usgs. gov). The ROE method was used for dissolved-solids analysis of 11 of the 23 samples collected during water years 2004-09. A regression equation was determined for the relation between ROE and specific conductance. This equation was then used to estimate dissolved-solids concentrations for the remaining 12 samples for which only specific conductance data were available (table 5).

On the basis of monitoring data, the annual dissolvedsolids load for Peoples Canal was estimated to be 8,900 tons (table 6). This value was subtracted from the adjusted dissolved-solids load (36,100 tons) determined for the Henrys Fork near Manila, Utah. The final adjusted dissolved-solids load (27,200 tons) determined for the Henrys Fork near Manila, Utah (using the SPARROW model and monitoring data for Antelope Wash and Peoples Canal) was similar to the original dissolved-solids load of 29,600 tons predicted by using the SPARROW model. These data indicate that the inclusion of Antelope Springs point source and water diversion in Peoples Canal did not substantially change the SPARROW prediction; therefore, the SPARROW predictions of dissolvedsolids load were used for further analysis as discussed in subsequent sections of this report.

The dissolved-solids load (29,600 tons) determined by using the SPARROW model for Henrys Fork near Manila, Utah, is 38 percent less than the estimated dissolved-solids load from the LOADEST model (47,600 tons) for the streamflow-gaging station at Henrys Fork near Manila, Utah (site 09229500) for water year 1991 (table 3). These data indicate that overall the SPARROW model underpredicted the dissolved-solids load by about 38 percent. Models like SPARROW are valuable for large-basin analyses and predicting dissolved-solids load in ungaged reaches; however, site-specific data are important for local managers and decision-making with regard to small watersheds.

\section{Determination of Dissolved-Solids Load for Upper Henrys Fork Basin}

A principle objective of this investigation was to estimate the annual dissolved-solids load for normal (mean) conditions in the upper Henrys Fork Basin, the $485-\mathrm{mi}^{2}$ drainage upstream from the confluence with Antelope Wash (fig. 1). Dissolved-solids and streamflow monitoring data do not exist for this location, and Henrys Fork near Manila, Utah, is the nearest monitoring site. SPARROW model simulations for the Upper Colorado River Basin were used to predict dissolvedsolids loads for water year 1991 at 57 locations throughout the Henrys Fork Basin, including Henrys Fork upstream from Antelope Wash. The dissolved-solids load predicted by using the SPARROW model for the Henrys Fork upstream from Antelope Wash (25,000 tons) for water year 1991 was 84 percent of the dissolved-solids load predicted by using the SPARROW model for Henrys Fork near Manila, Utah $(29,600$ tons) for water year 1991 . The application of this coefficient (0.84) to the 25-percent trimmed mean of the annual dissolved-solids load at Henrys Fork near Manila, Utah, estimated by LOADEST (44,300 tons), yielded an estimated annual dissolved-solids load in Henrys Fork upstream from Antelope Wash of 37,200 tons ( $\pm 2,800$ tons at the 95-percent confidence level; table 3).

The 25-percent trimmed mean was used because it represents a mean value less affected by extremes. The scientific objective for this study was to estimate the dissolved-solids load for the study area for mean conditions. By adjusting, and later comparing, the SPARROW results to the trimmed mean, a dissolved-solids load more representative of the mean dissolved-solids load was obtained. If the objective had been to compare SPARROW results for water year 1991, then the dissolved-solids load representative of 1991 rather than the mean dissolved-solids load would be presented. The 25-percent trimmed mean of the LOADEST estimated annual dissolved-solids load for Henrys Fork near Manila, Utah, of 44,300 tons is within the range of uncertainty of the SPARROW model prediction of 29,600 tons for the Upper Colorado River Basin.

\section{Distribution of Dissolved-Solids Load by Source at Selected Locations in Henrys Fork Basin}

In addition to providing estimates of dissolved-solids load at locations of interest, the SPARROW model for the Upper Colorado River Basin apportions the total dissolvedsolids load associated with each of the 11 defined sources. An objective of this investigation was to estimate the dissolvedsolids load associated with irrigated agricultural lands in the upper Henrys Fork Basin. As determined by the SPARROW model simulations, approximately 56 percent (14,000 tons) of the dissolved-solids load at Henrys Fork upstream from Antelope Wash $(25,000$ tons $)$ is associated with the 21,500 acres of irrigated agricultural lands (fig. 1). For comparison, at Henrys Fork near Manila, Utah, the 24,800 acres of irrigated agricultural lands in this 520- $\mathrm{mi}^{2}$ drainage area (David Eckhart, Bureau of Reclamation Remote Sensing and Geographic Information Group, written commun., September 28, 2006) contribute approximately 47 percent (17,000 tons) of the adjusted dissolved-solids load (36,100 tons) for the Henrys Fork near Manila, Utah, after adding in the contribution of Antelope Springs, which was not represented in the SPARROW model. No adjustments were made to the contributions of the 11 defined sources predicted by using the SPARROW model, except for the addition of the dissolvedsolids load from Antelope Springs. 
Table 5. Dissolved-solids concentration and estimated daily dissolved-solids load in Peoples Canal, Wyoming, June 2004 to September 2009.

$\left[\mathrm{ft}^{3} / \mathrm{s}\right.$, cubic feet per second; $\mu \mathrm{S} / \mathrm{cm}$, microsiemens per centimeter; ${ }^{\circ} \mathrm{C}$, degrees Celsius; ROE, residue on evaporation at $180^{\circ} \mathrm{C}$; mg $/ \mathrm{L}$, milligrams per liter; --, no data]

\begin{tabular}{|c|c|c|c|c|c|c|c|}
\hline Site number & Site name & $\begin{array}{c}\text { Sample } \\
\text { date }\end{array}$ & $\begin{array}{c}\text { Streamflow, } \\
\text { instantaneous } \\
\left(\mathrm{ft}^{3} / \mathbf{s}\right)\end{array}$ & $\begin{array}{c}\text { Specific } \\
\text { conductance } \\
\left(\mu \mathrm{S} / \mathrm{cm} \text { at } 25^{\circ} \mathrm{C}\right)\end{array}$ & $\begin{array}{c}\text { Dissolved-solids } \\
\text { concentration, ROE } \\
\text { (mg/L) }\end{array}$ & $\begin{array}{c}\text { Estimated daily } \\
\text { dissolved-solids } \\
\text { concentration' } \\
\text { (mg/L) }\end{array}$ & $\begin{array}{c}\text { Estimated daily } \\
\text { dissolved-solids } \\
\text { load }^{2} \\
\text { (tons) }\end{array}$ \\
\hline 410233109440901 & Peoples Canal at Henrys Fork & $6 / 29 / 2004$ & 50.0 & 1,130 & 808 & 808 & 109 \\
\hline 410233109440901 & Peoples Canal at Henrys Fork & $7 / 22 / 2004$ & 40.0 & 1,100 & -- & 827 & 89 \\
\hline 410233109440901 & Peoples Canal at Henrys Fork & $8 / 10 / 2004$ & 23.0 & 1,110 & 802 & 802 & 50 \\
\hline 410233109440901 & Peoples Canal at Henrys Fork & $9 / 14 / 2009$ & 24.0 & 1,540 & 1,210 & 1,210 & 78 \\
\hline 410233109440901 & Peoples Canal at Henrys Fork & $10 / 26 / 2004$ & 24.0 & 1,080 & -- & 811 & 52 \\
\hline 410233109440901 & Peoples Canal at Henrys Fork & $11 / 22 / 2004$ & 1.6 & 1,210 & 904 & 904 & 4 \\
\hline 410233109440901 & Peoples Canal at Henrys Fork & $6 / 1 / 2005$ & 41.0 & 390 & 265 & 265 & 29 \\
\hline 410044109405601 & Peoples Canal at Washam, WY & $7 / 10 / 2007$ & 4.8 & 1,190 & -- & 901 & 12 \\
\hline 410044109405601 & Peoples Canal at Washam, WY & $8 / 14 / 2007$ & 13.0 & 1,040 & 772 & 772 & 27 \\
\hline 410044109405601 & Peoples Canal at Washam, WY & $9 / 27 / 2007$ & 20.0 & 1,210 & -- & 917 & 49 \\
\hline 410044109405601 & Peoples Canal at Washam, WY & $10 / 16 / 2007$ & 27.0 & 902 & 661 & 661 & 48 \\
\hline 410044109405601 & Peoples Canal at Washam, WY & $11 / 7 / 2007$ & 2.6 & 840 & -- & 615 & 4 \\
\hline 410044109405601 & Peoples Canal at Washam, WY & $5 / 20 / 2008$ & 39.0 & 463 & 326 & 326 & 34 \\
\hline 410044109405601 & Peoples Canal at Washam, WY & $6 / 10 / 2008$ & 40.0 & 641 & -- & 452 & 49 \\
\hline 410044109405601 & Peoples Canal at Washam, WY & $7 / 17 / 2008$ & 28.0 & 1,060 & 784 & 784 & 59 \\
\hline 410044109405601 & Peoples Canal at Washam, WY & $8 / 25 / 2008$ & 15.0 & 1,460 & 1,170 & 1,170 & 47 \\
\hline 410044109405601 & Peoples Canal at Washam, WY & $9 / 30 / 2008$ & 14.0 & 1,250 & -- & 950 & 36 \\
\hline 410044109405601 & Peoples Canal at Washam, WY & $4 / 29 / 2009$ & 7.2 & 796 & -- & 579 & 11 \\
\hline 410044109405601 & Peoples Canal at Washam, WY & $5 / 19 / 2009$ & 24.0 & 357 & -- & 220 & 14 \\
\hline 410044109405601 & Peoples Canal at Washam, WY & $6 / 5 / 2009$ & 32.0 & 537 & 368 & 368 & 32 \\
\hline 410044109405601 & Peoples Canal at Washam, WY & $7 / 9 / 2009$ & 26.0 & 932 & -- & 690 & 48 \\
\hline 410044109405601 & Peoples Canal at Washam, WY & $8 / 4 / 2009$ & 25.0 & 1,270 & -- & 966 & 65 \\
\hline 410044109405601 & Peoples Canal at Washam, WY & $9 / 1 / 2009$ & 21.0 & 1,420 & -- & 1,089 & 62 \\
\hline
\end{tabular}

${ }^{1}$ Values were determined from analysis of residue on evaporation at $180^{\circ} \mathrm{C}$ (ROE) or by using regression equation developed from relation between ROE and specific conductance (SC): Dissolved solids concentration $=0.8176 \mathrm{SC}-72.19$.

${ }^{2}$ Individual average dissolved-solids concentrations $\left(D S_{\text {conc }}\right)$ were extrapolated to average daily dissolved-solids load (DSload) values by using the equation $D S_{\text {load }}=D S_{\text {conc }} \mathrm{x} 0.002697 \mathrm{x}$ streamflow, where streamflow is the instantaneous streamflow. 
Table 6. Estimated dissolved-solids load in Peoples Canal, Wyoming, June 2004 to September 2009.

[No samples were collected during December through March. --, not applicable]

\begin{tabular}{lccc}
\hline Period & Number of samples' & $\begin{array}{c}\text { Estimated mean daily } \\
\text { dissolved-solids load }^{2} \\
\text { (tons) }\end{array}$ & $\begin{array}{c}\text { Estimated mean dissolved- } \\
\text { solids load for period }^{3} \\
\text { (tons) }\end{array}$ \\
\hline April 15-30 & 1 & 11 & 180 \\
May & 2 & 24 & 740 \\
June & 4 & 55 & 1,650 \\
July & 4 & 52 & 1,600 \\
August & 4 & 47 & 1,400 \\
September & 4 & 56 & 1,700 \\
October & 2 & 50 & 1,550 \\
November 1-15 & 2 & 4 & 60 \\
April 15- November 15 & -- & -- & 8,900 \\
\hline
\end{tabular}

'Samples collected at either U.S. Geological Survey site 410233109440901 or 410044109405601.

${ }^{2}$ Values were determined from the mean value for the period from the estimated daily dissolved-solids load in table 5.

${ }^{3}$ Value was determined by multiplying days in period by the estimated mean daily dissolved-solids load in tons.

\section{Summary}

The Colorado River Salinity Control Forum has a goal of reducing dissolved-solids load in the Colorado River drainage system, including Henrys Fork. Irrigated agriculture has been the focal point of many projects because changes to infrastructure and irrigation practices can yield substantial reductions in dissolved-solids load. The Henrys Fork Basin upstream from Antelope Wash (drainage area of 485 square miles) includes about 21,500 acres of irrigated lands. The U.S. Geological Survey (USGS), in cooperation with the Bureau of Reclamation, conducted an investigation to estimate the dissolvedsolids load associated with irrigated agricultural lands upstream from Antelope Wash. Streamflow and water-quality data collected at Henrys Fork near Manila, Utah (USGS streamflow-gaging station 09229500), downstream from Antelope Wash were used to estimate annual dissolved-solids loads that were then compared to the dissolved-solids load for water year 1991 estimated by the SPAtially Referenced Regression On Watershed attributes (SPARROW) model for the Upper Colorado River Basin.

Annual dissolved-solids loads at Henry Fork near Manila, Utah, were estimated by using the LOAD ESTimator (LOADEST) computer program run as an add-on to S-PLUS. The annual dissolved-solids load for water years 1970-2009 ranged from 18,300 tons in 1977 to 123,300 tons in 1983. Annual streamflows for this period ranged from 14,100 acrefeet in 1977 to 197,500 acre-ft in 1983. The estimated mean annual dissolved-solids load for water years 1970-2009 was 48,700 tons, and the estimated median annual dissolvedsolids load for the same period was 45,400 tons. The annual dissolved-solids loads were ranked from largest to smallest, and 25 percent of the highest and lowest values were removed. Then the 25-percent trimmed mean of 44,300 tons was used as the best estimate of annual dissolved-solids load.

The predicted dissolved-solids load from the Upper Colorado River Basin SPARROW model at Henrys Fork near Manila, Utah, was 29,600 tons for water year 1991. Two features, Antelope Springs in Antelope Wash and Peoples Canal, which diverts water from Henrys Fork, were not represented in the SPARROW model and needed to be considered in order to compare results generated by the model with observed dissolved-solids load. The dissolvedsolids load associated with Antelope Springs (6,500 tons) was added to the SPARROW prediction and the dissolved-solids load diverted by Peoples Canal ( 8,900 tons) was subtracted from the SPARROW prediction for an adjusted dissolvedsolids load of 27,200 tons for water year 1991. The final adjusted dissolved-solids load (27,200 tons) determined for the Henrys Fork near Manila, Utah (using the SPARROW model prediction and monitoring data for Antelope Wash and Peoples Canal), was similar to the original SPARROW predicted dissolved-solids load of 29,600 tons. Therefore, the SPARROW predictions of dissolved-solids load were used for subsequent analyses.

A principle objective of this investigation was to estimate the annual dissolved-solids load in the upper Henrys Fork Basin for mean conditions. The dissolved-solids load predicted by using the SPARROW model for Henrys Fork upstream from Antelope Wash (25,000 tons) was 84 percent of the dissolved-solids load predicted by using the SPARROW model for Henrys Fork near Manila, Utah (29,600 tons). The application of this coefficient ( 0.84$)$ to the 25 -percent trimmed mean of annual dissolved-solids load at Henrys Fork near 
Manila, Utah, estimated by LOADEST (44,300 tons) yielded an estimated annual dissolved-solids load in Henrys Fork upstream from Antelope Wash of 37,200 tons $( \pm 2,800$ tons at the 95-percent confidence level).

The SPARROW model predicted that approximately 56 percent (14,000 tons per year) of the dissolved-solids load for water year 1991 at Henrys Fork upstream from Antelope Wash (25,000 tons) is associated with the 21,500 acres of irrigated agricultural lands. For comparison, at Henrys Fork near Manila, Utah, the 24,800 acres of irrigated agricultural lands in this 520-square-mile drainage area contributes approximately 47 percent (17,000 tons per year) of the adjusted dissolved-solids load (36,100 tons), after adding in the contribution of Antelope Springs, which was not represented in the SPARROW model.

\section{References Cited}

Cohn, T.A., 1988, Adjusted maximum likelihood estimation of the moments of lognormal populations from type I censored samples: U.S. Geological Survey Open-File Report 88-350, $34 \mathrm{p}$.

Colorado River Basin Salinity Control Forum, 1975, Proposed water quality standards for salinity including numerical criteria and plan of implementation for salinity control, Colorado River system: Denver, Colo., 134 p.

Colorado River Basin Salinity Control Forum, 2002, 2002 Review of water quality standards for salinity - Colorado River System: Denver, Colo., 188 p.

Fishman, M.J., and Friedman, L.C., 1989, Methods for determination of inorganic substances in water and fluvial sediments: U.S. Geological Survey Techniques of WaterResources Investigations, book 5, chap. A1, 545 p.

Gerner, S.J., Spangler, L.E., Kimball, B.A., and Naftz, D.L., 2006, Characterization of dissolved solids in water resources of agricultural lands near Manila, Utah, 2004-05: U.S. Geological Survey Scientific Investigations Report 2006-5211,36 p.

Helsel, D.R., and Hirsch, R.M., 2002, Statistical methods in water resources: U.S. Geological Survey Techniques of Water-Resources Investigations, book 4, chap. A3, 510 p.

Iorns, W.V., Hembree, C.H., and Oakland, G.L., 1965, Water resources of the Upper Colorado River Basin-technical report: U.S. Geological Survey Professional Paper 441, $370 \mathrm{p}$.
Kenney, T.A., Gerner, S.J., Buto, S.G., and Spangler, L.E., 2009, Spatially referenced statistical assessment of dissolved-solids load sources and transport in streams of the Upper Colorado River Basin: U.S. Geological Survey Scientific Investigations Report 2009-5007, 70 p., accessed August 17, 2009, at http://pubs.usgs.gov/sir/2009/5007.

Koenig, K.J., 1960, Bridger Formation in the Bridger Basin, Wyoming, in McGookey, D.P., and Miller, D.N., Jr., eds., Overthrust belt of southwestern Wyoming and adjacent areas: Wyoming Geological Association, 15th Annual Field Conference Guidebook, p. 163-168.

Love, J.D., and Christiansen, A.C., 1985, Geologic map of Wyoming: U.S. Geological Survey Map, scale 1:500,000.

Lowham, H.W., Peterson, D.A., Larson, L.R., Zimmerman, E.A., Ringen, B.E., and Mora, K.L., 1985, Hydrology of area 52, Rocky Mountain coal province, Wyoming, Colorado, Idaho, and Utah: U.S. Geological Survey Open-File Report 83-761, 96 p.

Mason, J.P., and Miller, K.A., 2004, Water resources of Sweetwater County, Wyoming: U.S. Geological Survey Scientific Investigations Report 2004-5214, 188 p.

Natural Resources Conservation Service, 2006, Plan and environmental assessment, Manila-Washam project area of the Colorado River Salinity Control Program, final draft, Sweetwater and Daggett Counties: United States Department of Agriculture, $112 \mathrm{p}$.

Runkel, R.L., Crawford, C.G., and Cohn, T.A., 2004, Load estimator (LOADEST) - a FORTRAN program for estimating constituent load in streams and rivers: U.S. Geological Survey Techniques and Methods, book 4, chap. A5, 69 p.

Schwarz, G.E., and Alexander, R.B, 1995, State Soil Geographic (STATSGO) data base for the conterminous United States: U.S. Geological Survey Open-File Report 95-449, digital map, scale 1:250,000, accessed September 16, 2009, at http://water.usgs.gov/lookup/getspatial? ussoils.

TIBCO Software, Inc., 2008, TIBCO Spotfire S+ 8.1 for Windows: Palo Alto, Calif., TIBCO Software, Inc., 572 p.

U.S. Department of Agriculture, 2004a, Ecological site descriptions, Agricultural Research Service, accessed January 29, 2010, at http://usda-ars.nmsu.edu/esd/esdIntro.html.

U.S. Department of Agriculture, 2004b, Soil survey of Henrys Fork Area, Utah-Wyoming - Part of Daggett and Summit Counties, Utah and Sweetwater and Uinta Counties, Wyoming: Natural Resource Conservation Service, 282 p., accessed January 7, 2010, at http://soildatamart.nrcs.usda. gov/Survey.aspx? State $=W Y$. 
U.S. Department of the Interior, 1999, Quality of waterColorado River Basin: Bureau of Reclamation Progress report no. 19, 93 p. plus appendix.

U.S. Department of the Interior, 2003, Quality of waterColorado River Basin: Salt Lake City, Utah, Progress Report 21, 95 p.

Publishing support provided by:

Denver Publishing Service Center

For more information concerning this publication, contact:

Director, Wyoming Water Science Center

U.S. Geological Survey

2617 East Lincolnway, Suite B

Cheyenne, Wyoming 82001

(307) 778-2931

Or visit the Wyoming Water Science Center Web site at: http://wy.water.usgs.gov/ 

